INSTITUTE OF FORESTRY • BELGRADE

INSTITUT ZA ŠUMARSTVO • BEOGRAD

SUSTAINABLE FORESTRY

COLLECTION 77-78, 2018
ODRŽIVO ŠUMARSTVO

ZBORNIK RADOVA 77-78, 2018

UDK 630*331.1+630*839.81]:662.63(497.11)

Original scientific paper

\title{
IMPROVING THE USE OF FOREST-BASED BIOMASS FOR ENERGY PURPOSES IN SERBIA
}

\author{
Ljiljana BRAŠANAC-BOSANAC ${ }^{l}$, Tatjana ĆIRKOVIĆ-MITROVIĆ , \\ Saša EREMIJA ${ }^{1}$, Snežana STAJIĆ ${ }^{1}$, Aleksandar LUČIĆ ${ }^{l}$
}

\begin{abstract}
Serbia is one of the countries of Southeastern Europe with significant potentials for using biomass from forests and wood processing industry in the form of wood residues for the production of modern fuels. This type of biomass has not been used efficiently. One of the reasons is the traditional use of firewood for domestic heating needs despite its lower energy efficiency compared to pellets and briquettes. According to FAO methodology, the estimated energy potential of the available biomass derived from forests and wood processing industry in Serbia amounts to 1.53 Mtoelyear. According to the Energy Sector Development Strategy of the Republic of Serbia for the period by 2025 with projections by 2030 together with relevant Decisions on the energy balance determination, the degree of the use of potentially available biomass from forests and wood processing industry is around 1.02 Mtoe/year (66.7\%). The remaining unused potential of this biomass is estimated at around 0.51Mtoe / year.

Besides the study of the state of biomass from forests and wood processing industry, the paper provides recommendations on how to increase the utilization rate of this biomass in Serbia.
\end{abstract}

Key words: forest-based biomass, potential, energy value, Serbia.

\section{UNAPREĐENJE KORIŠĆENJA BIOMASE IZ ŠUMARSTVA U ENERGETSKE SVRHE U SRBIJI}

Izvod: Srbija predstavlja jednu od zemalja u regionu Jugoistočne Evrope koja ima značajne potencijale za korišćenje biomase iz šumarstva i drvno-prerađivačke industrije u obliku drvnog ostatka za proizvodnju modernih goriva. Ovako dobijena biomasa se ne

\footnotetext{
${ }^{1}$ Institute of Forestry, 3 Kneza Višeslava, Belgrade, Serbia
} 
koristi efikasno, između ostalog zbog tradicionalnog korišćenja ogrevnog drveta za potrebe grejanja u domaćinstvima, koje ima nižu energetsku efikasnost u odnosu na pelete $i$ brikete. Po metodologiji FAO procenjena energetska vrednost potencijalno raspoložive biomase iz šumarstva $i$ drvno-prerađivačke industrije u Srbiji iznosi ukupno 1,53 Mtoe/godišnje. Prema Strategiji razvoja energetike Republike Srbije do 2025. godine sa projekcijama do 2030. godine, kao i odgovarajućim Odlukama o utvrđivanju energetskog bilansa, stepen korišćenja potencijalno raspoložive biomase iz šumarstva $i$ drvnoprerađivačke industrije iznosi oko 1,02 M toe/godišnje (66,7\%). Preostaje neiskorišćeni raspoloživi potencijal ove biomase, koji se procenjuje na oko 0,51Mtoe/godišnje.

$U$ radu će se, pored analize stanja biomase iz šumarstva i drvno-prerađivačke industrije, dati preporuke za povećanje stepena iskorišćenosti ove biomase u Srbiji.

Ključne reči: biomasa iz šumarstva, potencijal, energetska vrednost, Srbija.

\section{INTRODUCTION}

The demand for energy has been increasing with the increase in the world's population. In the near future, renewable energy sources (RES) will, therefore, get a key role in the supply of energy at a global level. Compared to oil, coal and natural gas, the share of renewable energy sources in the global energy consumption is only $2.8 \%$ in the world today (Statistical review of the world energy, 2016). Serbia also has an extremely low share of RES in the production of energy.

In the broadest sense, biomass is a matter of biological origin or organic matter that can be used in various ways and transformed into various forms of energy (heat, mechanical or electrical), gaseous, liquid or solid fuels (ĐurišićMladenović, et al, 2016).

Forest-based biomass belongs to solid biomass which includes firewood, plant mass of fast-growing plants, branches and wood waste from forests, sawdust, bark and wood residue from the wood-processing industry. Forest-based biomass has a dominant share of around $60 \%$ of the total energy produced from renewable sources in Serbia (Decisions on the energy balance determination in the Republic of Serbia for 2018, Official Gazette of the Republic of Serbia, No. 119/17).

Despite its great potential, the use of wood biomass in Serbia has not been efficient. Significant amounts of wood residue produced in the course of tree felling and timber assortment production are left unused in forests. The same applies to fine wood residues (sawdust) produced in the course of wood processing by sawmills in particular. This residue is then disposed of in the stockpiles next to the factories or burnt. Recent years have seen some shifts in the use of coarse wood residues produced by sawmills. They are sold to local people most commonly for domestic heating purposes. However, the scope of these shifts is not satisfactory.

With the aim of improving the use of biomass from forests and wood processing industry, the paper studies resources and gives recommendations for increasing the utilization of forest-based biomass for energy purposes in Serbia. 


\section{METHODOLOGY}

The research was based on the methods of analysis and synthesis used to determine the significance, potential and existing state of forest-based biomass, resulting in the effective solutions and proposals of measures that would increase the use of wood biomass for energy purposes in Serbia, in line with the national and EU legislation.

Data on the potential and actual biomass were obtained from the data analyzed in relevant scientific papers, studies, projects and monographs dealing with this issue, as well as legal regulations and data obtained from the Institute of Statistics of the Republic of Serbia, SE 'Srbijašume', SE 'Vojvodinašume' and other sources.

\section{RESULTS AND DISCUSSION}

The European Union does not prescribe how a state should organize its own forestry, whether there will be one or more enterprises, but it requires the legislation to be in accordance with the principles respected by European countries (the principle of sustainable development, ecological principles, Pan-European Criteria and Indicators, etc.). In accordance with the Kyoto Protocol, the Paris Agreement and the EU Directives, and based on the obligation to increase the share of renewable energy sources in the total energy consumption, a lot of EU countries are encouraging the use of biomass as fuel. Some developed countries have strong biofuel markets with a steady increase in demand for biomass as fuel, which creates tempting conditions for the export of biofuels to the EU market. High fossil fuel prices and political decisions directed toward increasing energy security and climate change mitigation provide a strong stimulus to the development of renewable energy sources, especially the wood-based energy.

Potential of renewable energy sources in Serbia - The Republic of Serbia has significant potential of RES. It is estimated at $\mathbf{5 . 6 5}$ Mtoe/year. Biomass potential accounts for more than $60 \%$ of it, which is about 3.45 Mtoe. 2.39Mtoe of it is unused and 1.05 Mtoe used biomass. Of the registered biomass potential, about 1.67 Mtoe is derived from agriculture and food processing industry, while forestbased biomass accounts for 1.53 Mtoe (Table 1).

Table 1. Available technical potential of renewable energy sources in the Republic

\begin{tabular}{|c|c|c|c|}
\hline Type of RES & $\begin{array}{c}\text { Available realized } \\
\text { technical potential } \\
\text { (Mtoe) }\end{array}$ & $\begin{array}{c}\text { Unrealized available } \\
\text { technical potential } \\
\text { (Mtoe) }\end{array}$ & $\begin{array}{c}\text { Total } \\
\text { available technical } \\
\text { potential (Mtoe) }\end{array}$ \\
\hline BIOMASS & 1.054 & 2.394 & 3.448 \\
\hline Agricultural biomass & 0.033 & 1.637 & 1.670 \\
\hline Agricultural crop residue & 0.033 & 0.99 & 1.023 \\
\hline $\begin{array}{l}\text { Residue from fruit growing, } \\
\text { viticulture and fruit processing }\end{array}$ & - & 0.605 & 0.605 \\
\hline Liquid manure & - & 0.042 & 0.042 \\
\hline Wood(forest-based) biomass & 1.021 & 0.509 & 1.530 \\
\hline Energy plantations & - & - & not available \\
\hline Biodegradable waste & 0 & 0.248 & 0.248 \\
\hline Biodegradable municipal waste & 0 & 0.205 & 0.205 \\
\hline
\end{tabular}




\begin{tabular}{|l|r|r|r|}
\hline \multicolumn{1}{|c|}{ Type of RES } & \multicolumn{1}{|c|}{$\begin{array}{c}\text { Available realized } \\
\text { technical potential } \\
\text { (Mtoe) }\end{array}$} & $\begin{array}{l}\text { Unrealized available } \\
\text { technical potential } \\
\text { (Mtoe) }\end{array}$ & \multicolumn{1}{c|}{$\begin{array}{c}\text { Total } \\
\text { available technical } \\
\text { potential (Mtoe) }\end{array}$} \\
\hline $\begin{array}{l}\text { Biodegradable waste (excluding } \\
\text { municipal) }\end{array}$ & 0 & 0.043 & 0.043 \\
\hline HYDROENERGY & 0.909 & 0.770 & $\mathbf{1 . 6 7 9}$ \\
\hline GEOTHERMAL ENERGY & $\approx 0$ & 0.1 & 0.180 \\
\hline SOLAR ENERGY & $\approx 0$ & 0.240 & $\mathbf{0 . 1 0 3}$ \\
\hline WIND ENERGY & $\approx 0$ & $\mathbf{0 . 1 0 3}$ & $\mathbf{5 . 6 5}$ \\
\hline Total from all RES & $\mathbf{1 . 9 6 8}$ & $\mathbf{3 . 6 8 2}$ & \\
\hline
\end{tabular}

Source: Energy Sector Development Strategy of the Republic of Serbia for the period by 2025 with projections by 2030

Potentially available forest-based biomass - The energy potential of wood biomass (which is the most common biomass in Central Serbia) originating from forests and wood processing industry (tree felling and wood residues produced during primary and/or industrial wood processing) is 1.53 Mtoe. According to the Energy Sector Development Strategy of the Republic of Serbia for the period by 2025 with projections by 2030 together with relevant Decisions on the energy balance determination, the degree of the utilization of potentially available biomass from forests and wood processing industry is around 1.02 Mtoe/year (66.7\%), (Table 2).

Table 2. Potential and actual wood biomass from forests and wood processing industry: energy potential

\begin{tabular}{|c|c|c|}
\hline \multirow{3}{*}{$\begin{array}{c}\text { Biomass from } \\
\text { forests and wood } \\
\text { processing }\end{array}$} & $\begin{array}{c}\text { Energy potential } \\
\text { (GJ) }\end{array}$ & $\begin{array}{c}\text { Energy potential } \\
\text { (toe) }\end{array}$ \\
\cline { 2 - 3 } industry & \multicolumn{2}{|c|}{ Potentially available wood biomass } \\
\cline { 2 - 3 } & 63.960 .822 & 1.527 .678 \\
\cline { 2 - 3 } & Degree of potentially available wood biomass utilization \\
\cline { 2 - 3 } & 42.747 .228 & 1.021 .000 \\
\hline
\end{tabular}

Source: Renewable Energy National Action Plan of the Republic of Serbia (Official Gazette RS, 53/2013) and the Energy Sector Development Strategy of the Republic of Serbia for the period by 2025 with projections by 2030, (Official Gazette of RS, No. 101/2015).

Based on the results of TCP/FAO project 'Wood-based energy for sustainable rural development in Serbia (FAO, 2011), the total annual consumption of wood for domestic heating purposes in 2010 was $6.360 .788 \mathrm{~m}^{3}$. Besides this quantity of firewood, an additional $55.905 \mathrm{~m}^{3}$ of coarse wood residue originating from wood processing was used for the same purpose (Glavonjić, 2010, 2011).

According to data of the Ministry of Energy, Development and Environmental Protection (2013) on the structure of the domestic primary energy production for 2013, the share of renewable energy sources was 1.835 Mtoe, which was $16 \%$ of domestic primary energy production, with the largest share of solid biomass $(58 \%)$ and hydropower $(41 \%)$, while biogas, wind, solar and geothermal energy participated with less than $1 \%$.

Projects, scientific papers and studies (Vasiljević, 2015, Glavonjić, 2010, 2016 etc.), conducted in the period from 2013 to 2018, in which the real production and consumption of firewood in Serbia were analyzed, point to the fact that the 
current state of the solid biofuel market in Serbia is characterized by a rapid growth in the production and consumption of all types of wood fuel in the past five years. Furthermore, the largest increase was achieved in the production of wood chips and wood pellets, while the production and consumption of firewood, wood briquettes and charcoal have not changed significantly over the last five years.

Despite the great potential of wood mass in Serbia, both in terms of its biological diversity and in terms of its distribution, forest-based biomass has not been used sufficiently for the purpose of energy production (excluding the use of firewood for domestic heating). There are several reasons: low-cost electricity, unsolved logistics problems in the collection and distribution, the absence of a regulated biomass market and appropriate technologies for its use as fuel. We must further add the poor financial power of potential buyers and expensive commercial loans, as well as the lack of state subsidies for the construction of biomass plants.

There are numerous reasons for the insufficient utilization of potentially available wood biomass, such as:

- Poorly developed forest road infrastructure (insufficiently opened) and difficult accessibility (terrain with extremely unfavorable orographic characteristics and poor access to forest stands). At sites that are characterized by good openness and where machinery can be used in the process of forest utilization, fine branch timber and waste from felling and assortment production can be extracted from the forest with minimum investments. On the other hand, in the areas with extremely unfavorable orographic characteristics and poor access to forest stands, the profitability of the collected products is disputable;

- Inappropriate mechanization for the collection and transportation of wood biomass, i.e., high costs of biomass collection at the felling site for its further manipulation (making the collection of forest residue unprofitable);

- The fragmentation of privately-owned forest plots (on average 0.3 ha in Serbia), and long distances between them affect the felling and extraction of wood resources, which significantly reduces their availability (Ratknić et al., 2007);

- Demographic emptying of villages and border settlements, together with the economic underdevelopment of local communities and extreme poverty of the population, especially in the Southern and Eastern Serbia, limits the possibilities of collecting and using this biomass. Namely, the municipalities in Serbia that are rich in forests ${ }^{2}$ are demographically poor and economically less developed and these facts make an obstacle to the efficient use of forest-based biomass;

- Through the process of forest resource utilization, it should be ensured that certain quantities of wood are left in stands in order to preserve and improve the quality of soil and the state of biodiversity;

${ }^{2}$ Out of 146 municipalities in Serbia, 28 municipalities have the area covered in forest larger than $40 \%$ of the territory of the municipality. 
- Considering the use of sawmill timber residue, significant quantities of sawdust from different stockpiles can become unusable because long exposure to adverse atmospheric conditions makes sawdust severely prone to decay. Besides, various types of mechanical waste (stone, metal, sheet metal, etc.) are disposed of at such stockpiles, thus additionally complicating the process of biomass use for the production of wood fuels. It is difficult to estimate the amount of sawdust currently found in stockpiles that can be really used for the production of wood-based biomass. In any case, sawdust found in the stockpiles about five years old can largely be used for the production of fuelwood.

In the structure of the final consumption of biomass from forests and wood processing industry, the industry accounts for $13 \%$, households for $84 \%$ (use of firewood for heating purposes), and other sectors for 3\%, with extremely small amount spent in heating plants (Official Gazette RS, No. 119/17). There are numerous reasons for such a structure of consumption:

$\checkmark$ Rural areas and peripheral parts of suburban areas, where households mostly use firewood for heating purposes, gravitate towards the areas with high production of timber or they are far from other supply sources, while households` low purchasing power makes firewood the most affordable heating alternative;

$\checkmark$ Insufficient incentive measures of the state in the field of biomass and its use for energy purposes (construction of biomass power plants);

$\checkmark$ Limited economic power of potential investors interested in investing money in the biomass sector (construction of power plants, cogeneration plants);

$\checkmark$ Unfavourable commercial loans and loan terms and conditions;

$\checkmark$ Lack of financial resources of households, small businesses and institutions to change the heating mode (to buy pellet boilers), etc.

\section{CONCLUSIONS}

Biomass is the only form of renewable energy source that can be used to produce liquid fuel whose consumption exceeds other energy sources, with projections that it won`t change after 2030 (Đurišić-Mladenović, et al., 2016).

It is necessary that wood and wood biomass be given the right importance, not only in energy balances and official consumption analyses in Serbia but also in the application of methods for estimating its consumption. The methods of firewood consumption estimation must be comprehensive and elaborate, based on recognized scientific and statistical methods. Furthermore, the credibility of data should be checked in both directions, in the direction of wood production and in the direction of its consumption.

Recent years have seen some shifts in the use of coarse wood residues produced by sawmills. They are sold to local people most commonly for domestic heating purposes. However, there are significant amounts of wood residue that are still unused. 
Although energy crop plantations have great energy potential (Mitrović et al., 2011), the areas under these crops in Serbia are rather small and the actual biomass derived from energy plants is very small.

How to improve the use of biomass for energy purposes? Although firewood has lower energy efficiency than pellets and briquettes, it will be still used by households in the future due to the low purchasing power of the population, high prices of conventional fuels (fuel oil, liquefied gas, coal), slow development of gas distribution network and costly gas installation (without subsidies and favourable loan conditions), inability of households to afford the purchase of boilers and pellet heating stoves.

These are recommendations for more efficient use of wood biomass for energy purposes:

- state incentive measures to increase the use of pellets and briquettes in households (for the heating of households, auxiliary facilities and greenhouses), industrial plants (for instance in raw material drying) and small boiler rooms for heating buildings and public institutions (e.g., hotels, health centers, schools, kindergartens);

- the use of solid biomass in bio-plants and cogeneration plants in which biomass is used as the primary energy source for the production of electricity and heat;

- the best way to use waste biomass from the wood processing industry for the purpose of energy production in industrial or district heating plants is to use it in the area close to the place of its collection;

- the establishment of intensively managed forest plantations of fast-growing tree species in Serbia should also be considered as a possible solution for meeting the ever-growing energy needs by using renewable energy sources, which would further reduce the pressure on forests (unproductive areas of agricultural and forest land would be given purpose and the engagement of local workforce and professional support would provide additional funding sources);

- potential growers of energy crops are not sufficiently familiar with the comparative advantages of energy crops of the second generation biofuels, nor with the technology of their cultivation, which makes education in this area very important in the coming period.

The use of biomass from forests and wood processing industry in Serbia will not be satisfactory enough until investments are encouraged and stimulated, especially for the establishment of a district pellet heating system. Also, the proposed supply of energy for the use of the biomass will necessitate the improvement of legal regulations and technical standards, introduction of concrete and systematic support measures for the construction of power plants and cogeneration plants, provision of favourable loans for the energy conversion in heating plants, etc. 
Note: The paper is part of the results of the project SocioNext SE: More Inclusive, Clean and Affordable Biomass Energy Production from Agricultural Residues and Waste", no. 48-00-00203 / 2014-28-19

\section{REFERENCES}

Đurišić-Mladenović, N., Predojević, Z., Škrbić, B. (2016): Conventional and Advanced Liquid Biofuels, Chemical Industry, vol. 70, no. 3, p. 225-241.

Wood-based energy for sustainable rural development in Serbia, FAO Project, 2011.

Glavonjić, B. (2010): Possibilities, challenges and current progress in the development of the wood biomass market in Montenegro - Final report, Ministry of Agriculture, Forestry and Water Management of Montenegro \& LUX - development Luxembourg.

Glavonjić, B. (2011): Woodfuels: types, characteristics and benefits for heating, SNV Montenegro, Podgorica, Montenegro.

Glavonjić, B., Lazarević, A., Čomić, D. (2016): Impact of wood pellets export on the development of their production in Serbia with the effects of substituting enegry from fossil fuels and reduction of carbon dioxide emission, Bulletin of the Faculty of Forestry, no. 114, University of Belgrade, Faculty of Forestry, p. 55-74.

Mitrović, S., Veselinović, M., Vilotić, D., Čule, N., Dražić, D., Nikolić, B., Nešić, M. (2011): Temporary deposited of deposol as the possible area for short rotation plantation establishment - model case, Sustainable Forestry, Collection 63-64, pp. 77-85

Renewable Energy National Action Plan of the Republic of Serbia, RS Official Gazette, No. 53/2013.

Decision on the Energy Balance Determination in the Republic of Serbia for 2018, Official Gazette of RS no. 119/17.

Spatial Plan of the Republic of Serbia 2010-2014-2021, Draft, CD.

Ratknić, M, Rakonjac, Lj., Veselinović, M. (2007): Sustainable use of forests and forest ecosystems - the state of indicators in Serbia. Institute of Forestry Proceedings, 56, Belgrade, pp. 29-56.

Regional Spatial Plan of the Autonomous Province of Vojvodina by 2020, Official Gazette APV no. 22/2011, 2011.

Statistical review of world energy, 2016, http://www.bp.com/en/global/corporate/energy-economics/statistical-review-of-worldenergy.html.

Statistical Yearbook of the Republic of Serbia, Statistical Office of the Republic of Serbia, 2017.

Energy Sector Development Strategy of the Republic of Serbia for the period by 2025 with projections by 2030. 
Study of the establishment of intensively managed forest plantations for energy and other purposes with the Manual on their establishment, Institute for Forestry, Belgrade, on request of the Forest Directorate, 2016.

Vasiljević, A. (2015): The impact of the wood market on the socio-economic component of the sustainable development of the wood sector in Serbia. Ph.D. thesis, University of Belgrade, Faculty of Forestry, Belgrade, 1-224.

http://www.crops4energy.co.uk/interested-in-growing-woody-energy-crops-free-rokwoodtraining-course/\#!lightbox/2/

https://www.eevrbas.org/korisni-saveti/grejanje/81-grejanje-biomasom

https://www.energetskiportal.rs/obnovljivi-izvori-energije/biomasa/

\title{
IMPROVING THE USE OF FOREST-BASED BIOMASS FOR ENERGY PURPOSES IN SERBIA
}

\author{
Ljiljana BRAŠANAC-BOSANAC, Tatjana ĆIRKOVIĆ-MITROVIĆ, \\ Saša EREMIJA, Snežana STAJIĆ, Aleksandar LUČIĆ
}

\section{Summary}

In the last few years significance of biomass started to grow again, due to exhaustion of fossil fuel reserves and their negative impact on climate and environment. Utilization of biomass in the political context of the modern world enables countries to increase their energy independence. In the Balkans, biomass is the most significant renewable energy source, due to abundance of forests and agricultural areas. Despite its great potential, the use of wood biomass in Serbia has not been efficient. Significant amounts of wood residue produced in the course of tree felling and timber assortment production are left unused in forests. Of the registered biomass potential, about 1.67 Mtoe is derived from agriculture and food processing industry, while forest-based biomass accounts for 1.53 Mtoe. Intensive use of forest biomass requires the establishment of system measures for control and supervision in the chain of use as well as the adaptation of the planning and forest management pattern. On this moment in Serbia legislative and regulatory frameworks and support mechanisms aimed to increase the usage of biomass and other renewable energy sources are developing. Investors interested in biomass utilization in district heating (DH) systems and combined heat and power (CHP) plants are also present. However, despite all potential and advantages of biomass and the existence of potential investors, we cannot be satisfied with the level and modes of utilization for energy production in Serbia. It is necessary that wood and wood biomass be given the right importance, not only in energy balances and official consumption analyses in Serbia but also in the application of methods for estimating its consumption. It must not be allowed for the increase of woody biomass demand to lead to the increased pressure on forests and exceeding of allowed cuts. In that case, positive effects of biomass use on one side could lead to the degradation of forests on the other. In order to improving the use of forest-based biomass for energy purposes in Serbia it is necessary to adopt relevant measures existing in other European countries and the regulations harmonized among decision makers in the fields of agriculture, forestry, energy and environmental protection. 


\title{
UNAPREĐENJE KORIŠĆENJA BIOMASE IZ ŠUMARSTVA U ENERGETSKE SVRHE U SRBIJI
}

\author{
Ljiljana BRAŠANAC-BOSANAC, Tatjana ĆIRKOVIĆ-MITROVIĆ, \\ Saša EREMIJA, Snežana STAJIĆ, Aleksandar LUČIĆ
}

\section{Rezime}

Zbog iscrpljivanja rezervi fosilnih goriva i njihovog negativnog uticaja na klimu i životnu sredinu, korišćenje biomase poslednjih nekoliko godina opet privlači pažnju javnosti. Korišćenje biomase u političkom kontekstu savremenog sveta omogućava državama da povećaju energetsku nezavisnost. Na Balkanu, biomasa je najznačajniji obnovljivi izvori energije, zbog obilja šuma i poljoprivrednih površina. Uprkos velikom potencijalu, upotreba drvne biomase u Srbiji nije bila efikasna. Značajne količine drvnog ostatka nastalog pri seči drveta i proizvodnji drvnih sortimenata ostaju neiskorišćene u šumama. Od registrovanog potencijala biomase, oko 1,67 Mtoe proizilazi iz poljoprivredne i prehrambene industrije, a biomasa zasnovana na šumama čini 1,53 Mtoe. Intenzivna upotreba šumske biomase zahteva uspostavljanje sistemskih mera za kontrolu i nadzor u lancu korišćenja, kao i prilagođavanje šeme planiranja i upravljanja šumama. U Srbiji se trenutno radi na unapređenju zakonodavnih i regulatornih okvira i mehanizama podrške sa ciljem povećanja upotrebe biomase i drugih obnovljivih izvora energije. Postoje i potencijalni investitori zainteresovani za korišćenje biomase u sistemima daljinskog grejanja (DH) i kombinovanim toplotnim i energetskim postrojenjima (CHP). Međutim, uprkos svim potencijalima i prednostima biomase i postojanju potencijalnih investitora, ne možemo biti zadovoljni nivoom i načinima upotrebe za proizvodnju energije u Srbiji. Neophodno je da se biomasi iz šumarstva da pravi značaj, ne samo u energetskim bilansima i službenim analizama potrošnje u Srbiji, već i u primeni metodologije za procenu njene potrošnje. Ne sme se dozvoliti povećana potražnja drvne biomase dovede do povećanog pritiska na šume i prekomerne seče. U tom slučaju, pozitivni efekti upotrebe biomase sa jedne strane mogu dovesti do degradacije šuma s druge strane. Da bi se unapredilo korišćenje biomase iz šumarstva u energetske svrhe u Srbiji, potrebno je usvojiti relevantne mere koje postoje u drugim evropskim zemljama i prateće propise usaglašene među donosiocima odluka iz oblasti poljoprivrede, šumarstva, energetike i zaštite životne sredine. 